\title{
PENDIDIKAN ISLAM PADA MASA DAULAH FATIMIYAH DI MESIR
}

\author{
Aidil Saputra \\ Sekolah Tinggi Agama Islam Negeri Teungku Dirundeng Meulaboh \\ aidilmbo@gmail.com \\ Abstrak
}

Menunjukan Pertama, selama dua abad lebih Dinasti Fatimiyah menguasai Mesir, keberadaan Dinasti Fathimiyah telah memberikan sumbangan peradaban yang besar. Kemajuan terbesar adalah memberikan ruang berkembangnya ilmu pengetahuan di dunia Islam yang melahirkan banyak ilmuwan, tertatanya sistem administrasi pemerintahan yang membuahkan kemakmuran, terkenal dengan toleransi beragamanya. Kedua, Dinasti Fatimiyah adalah satu-satunya dinasti Syi'ah dalam Islam yang eksis selama kurang lebih dua setengah abad dan bisa berjaya melampaui capaian wilayah kekuasaan kerajaan-kerajaan Islam terdahulu, dan telah memberi banyak sumbangan peradaban terhadap dunia Islam, khususnya Mesir, karena pada masa Dinasti Fatimiyah ini, Mesir mengalami tingkat kemakmuran dan vitalitas kultural yang mengungguli Irak dan Baghdad sebagai pusat kekuasaan Islam kala itu. Dalam kontek pendidikan dinasti fatimiyah menjadi rujukan pada masa tersebut dibelahan dunia islam bahkan pada masa sekarang dan menjadi rujukan pendidikan dibelahan dunia islam. kemajuan yang cukup pesat. Perkembangan intelektual pada dinasti ini memberi kontribusi yang besar bagi perkembangan ilmu pengetahuan dunia Timur dan Barat: meliputi perkembangan ilmu agama dan umum sehingga sampai sekarang pun masih dapat kita lihat perkembangannya.

Kata kunci: Pendidikan, Islam, Dinasti, Fatimiyah

\section{Abstract}

During the Fatimid Dynasty, Islamic education was growing rapidly and advanced. The First, for more than two centuries the Fatimid controlled Egypt, the existence of the Fatimid dynasty had contributed greatly to civilization. The greatest progress is to provide space for the development of science in the Islamic world that has given birth to many scientists, an organized system of government administration that has resulted in prosperity, known for its diversity of tolerance. Second, the Fatimid dynasty was the only Shi' ite dynasty in Islam that existed for approximately two and a half centuries and could prevail over the territorial achievements of the previous Islamic kingdoms, and had contributed a lot of civilization to the Islamic world, especially Egypt, because in During the Fatimid dynasty, Egypt experienced a level of cultural prosperity and vitality that surpassed Iraq and Baghdad as the center of Islamic power. In the context of education, the Fatimid dynasty became a reference at that time in parts of the Islamic world even today and has become a reference for education in parts of the Islamic world, quite rapid progress. The intellectual development of this dynasty made a major contribution to the development of science in the East and West world; covering the development of religious and general science so that we can still see its development today.

Key words: Education, Islam, Fatimid Dynasty 


\section{PENDAHULUAN}

Tidak dapat dipungkiri sesungguhnya perkembangan intelektual yang berkembang dan Berjaya sekarang di Barat berasal dari ilmuwanilmuwan muslim melalui sarana penerjemahan pengetahuan dari bahasa arab kedalam bahasa latin yang kemudian tersebar ke Eropa. Dengan demikian selama ini bagaikan para sejarawan sengaja menyembunyikan/menutupi usaha pengembangan intelektual yang telah dilakukan para ilmuan muslim pada masa kejayaan dan keemasan kebudayaan keraaan Islam. Diantara kerajaan islam yang banyak menghasilkan ilmuan muslim adalah Dinasti Fathimiah (296$555 \mathrm{H} /$ 908-1171 M). seperti yang dikatakan oleh Syed Ameer Ali bahwa "dibawah kaum fathimiah di Mesir, kairo telah menjadi pusat intelektual dan ilmiah baru. ${ }^{1}$

Pada masa inilah yang disebut oleh Harun Nasutioan sebagai periode klasik (650$1250 \mathrm{M})$ yang merupakan masa kemajuan. Di masa inilah berkembang ilmu pengetahuan, baik dalam bidang agama maupun non agama dan kebudayaan Islam. Pada zaman ini dihasilkan ulama-ulama besar seperti imam Mazhab, Tasawuf, dan Filsafat. Dalam tulisan ini penulis mencoba memaparkan kemajuan intelektual yang berkembang pada masa kejayaan Islam khususnya pada masa dinasti Fatimiah, yaitu mengenai sekolah dan juga bidang ilmu yang berkembang saat itu.

\section{PENDIDIKAN ISLAM PADA MASA} DAULAH FATIMIYAH DI MESIR

A. Terbentuknya Daulah Fatimiyah (297567 H/ 909-1171 M) bermazhab Syiah

1 Syed Ameer Ali, The Spirit of Islam. Diterjemahkan oleh Ahmadi Api Islam, Jakarta: Bulan Bintang, 1978, h. 548.
Ismailiyah. $^{2}$

Fatimiyah didirikan oleh Ubaidillah al-Mahdi yang datang dari Syiria Ke Afrika Utara Menisbahkan nasabnya sampai ke putri Rasulullah dan istri Khalifah Keempat Ali Bin Abi Thalib. Karena itu dinamakan Dinasti Fatimiyah, namun di kalangan Sunni mengatakan Al Ubaidiyyun. ${ }^{3}$ (khalifah pertama Dinasti Fatimiyah) dan barasal dari Yahudi. Konsep yang digunakan adalah syiah radikal Isma'iliyah dengan doktrin-doktrinnya yang berdimensi politik, agama, filsafat dan sosial. Serta para pengikutnya mengharapkan kemunculan Al-Mahdi.

Ubaidillah dengan dukungan kaum Barbar, pertama dapat mengalahkan gubenur-gubenur Aghlabiyah di Ifriqiah,Rustamiyah di Tahart dan menjadika Idrisiyah Fez sebagai bawahannya, saat pemerintah pertama kali pemerintah fatimiyah mengembangkan sayapnya ke daerah sekitarnya serta menduduki Mesir.

Dalam bersaing dengan pemerintahan Abbasiyah, Fatimiyah memindahkan ibukotanya dari al-Mahdi ke kairo, juga memeberi gelar kepada Khalifah-khalifah fatimiyah sebagai Khalifah sejati,dia juga menyebarkan da'i-da'inya (lulusan dari Universitas al-Azhar) ke luar mesir.

Pada pemerintahan Fatimiyah

2 http://fitrianimaduddin.wordpress. com/2010/01/07/dinasti-dinasti-lokal-dan-akhir-sejarahabasiyah

3 Ali Mufrodi, Islam dikawasan kebudayaan arab, Jakarta: Logos Wacana Ilmu, 1997, h. 109. 
timbul Perang Salip dan muncul gerakan-gerakan Syiah yang ekstrim. Berdirinya dinasti ini bemula menjelang kekuasaan bani Abbasiyah di Baghdad mulai melamah dan wilayah kekuasaanya yang sangat luas sehingga tidak terkoordinir lagi. Kondisi seperti inilah yang membuka peluang bagi munculnya dinasti-dinasti kecil di daerah-daerah,terutama di daerah yang gubernur dan sultannya memiliki tentara sendiri.Kondisi ini telah menyulut pemberontakan dari kelompokkelompok yang selama ini merasa tertindas serta memberi kesempatan bagi kelompok Syiah, Khawarij dan kaum mawali untuk melakukan kegiatan politik.Dinasti Fatimiyah bukan hanya sebuah wilayah yang gubenurnya yang independen,melainkan juga sebuah rezim revolusioner yang mengklaim otoritas unifersal. Mereka mendeklarasikan adanyakonsep imamah yakni para pemimpin dari keturunan Ali yang mengharuskan sebuah redefinisi mengenai pergantian sejarah Imam atau mengenai siklus eskatologis sejarah.

Dinasti Fatimiyah berkuasa mulai (909-1173 M) atau kurang lebih 2,5 abad lamanya dan Fatimiyah telah mencapai kemajuan yang pesat,terutama pada masa Al-Muiz, Al-Aziz dan Al-Hakim. Kemajuan-kemajuan itu mencakup berbagai bidang yaitu:

a. Kemajuan dalam hubungan perdagangan dengan dunia non Islam,termasuk india dan negeri-negeri Meditarenia yang Kristen.

b. Kemajuan bidang seni,diantaranya sejumlah dekorasi dan arsitektur istana.

c. Dalam bidang pengetahuan/pendidikan dengan dibangunnya Universitas Al-ahzar.

d. Dibidang ekonomi, baik sector pertanian,perdagangan maupun industri.

e. Dibidang keamanan.

Sesudah berakhirnya masa pemerintahan Al-aziz, pamor dinasti ini mulai menurun. Walaupun pada masa al-Munthasir sempat mengalami kejayaan, ini tidak sebagaimana yang dicapai oleh al-Azis. Adapun faktorfaktor yang menyebabkan kemunduran Dinasti Fatimiyah adalah:

a. Para penguasa yang selalu tenggelam dalam kehidupan mewah.

b. Adanya pemaksaan ideologi Syiah kepada masyarakat yang mayoritas sunni.

c. Terjadinya persaingan perebutan wazir.

d. Kondisi Al-Adhid (dalam keadaan sakit) yang di manfaatkan oleh Nur ad-Din,

Dalam kondisi khilafah yang sedang lemah,konflik kepentingan yang berkepanjangan diantara pejabat dan militer. Merasa tidak sanggup, akhirnya al-Zafir meminta bantuan kepada Nur al-Din dengan pasukan yang dipimpin oleh Salahuddin Al-Ayyubi. Mulamula ia berhasil membendung invansi tentara salib ke mesir.akan tetapi kedatangan Salahuddin untuk yang kedua kalinya tidak hanya memerangi tentara salib, tetapi untuk menguasai Mesir.dengan dikalahkanya tentara Salib sekaligus dikuasainya Mesir,maka berakhirlah riwayat Dinasti Fatimiyah di Mesir pada tahun $1171 \mathrm{M}$ yang telah bertahan selama 262 tahun.

Adapun para Khalifah Dinasti Fatimiyah Penguasa Cairo, diantaranya adalah:

1. Khalifah Ubaidillah Al-Mahdi (910- 
934). Dia adalah pendiri Dinastii Fatimiyah.

\section{B. Pendidikan Islam Pada Masa Daulah Fatimiyah di Mesir.}

2. Abu al-Qasim Muhammad al-Qa'im bi-Amr Allah bin al-Mahdi Ubaidillah (934-946).

3. Isma'il al-Mansur bi-1lah (946-953).

Pada masa ini ulama membagi ilmu pengetahuan kepada dua macam:

1. Ilmu yang berhubungan dengan al-Qur'an al-Karim

4. Abu Tamim Ma'add al-Mu'izz liDin Allah (953 M - 975) M. Mesir ditaklukkan semasa pemerintahannya.

5. Abu Mansur Nizar al-'Aziz bi-llah (975 M - 996 M).

6. Abu 'Ali al-Mansur al-Hakim bi-Amr Allah (996M - $1021 \mathrm{M})$.

7. Abu'l-Hasan 'Ali al-Zahir li-I'zaz Din Allah (1021 M - 1036 M).

8. Abu Tamim Ma'add al-Mustanhir bi1lah (1036 M - 1094 M).

9. Al-Musta'li bi-llah (1094 M - $1101 \mathrm{M})$. Pertikaian atas suksesinya menimbulkan perpecahan Nizari.

10. All-Amir bi-Ahkam Allah (1101 M 1130 M). Penguasa Fatimiyah di Mesir setelah tak diakui sebagai Imam oleh tokoh Ismailiyah Mustaali Taiyabi.

11. Abd al-Majid (1130 M - $1149 \mathrm{M})$.

12. Al-Wafir (1149 M - $1154 \mathrm{M})$.

13. Al-Fa'iz (1154 M - $1160 \mathrm{M})$.

14. Al-'Adid (1160 M - $1171 \mathrm{M})$ : Setelah jatuhnya Al-`Adid, kekuasaan Dinasti

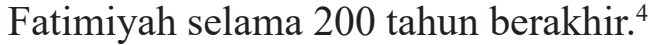

2. Ilmu pengetahuan yang bukan bersumber dari Arab.

Ilmu yang bersumber dari al-Qur'an disebut dengan ilmu naqliyah atau syar'iyyah sedang utuk katagori yang kedua disebut degan ilmu 'aqliyah atau hukmiyah, kadang juga disebut dengan ilmu 'azam.Adapun yang termasuk ilmu Naqliyah adalah; Ilmu Tafsir, qiraat, Ilmu hadits, fikih, ilmu kalam, nahwu, lughah, al-Bayan, dan Adab. Sedangkan yang termasuk ilmu Aqliyah ialah; Filsafat, Arsitektur, ilmu Nujum, music, kedokteran, sihir, kimia, matematika, sejarah dan geografi. ${ }^{5}$

Dinasti Fatimiyah memiliki perhatian besar terhadap perkembangan ilmu pegetahuan dan intelektual. Hal ini terbukti ketika pembangunan Masjid Al-Azhar dan Dar alHikmah, serata melahirkan banyak pakar dalam pelbagai disiplin ilmu.

Ajid Thohir dalam Perkembangan Peradaban di Kawasan Dunia Islam menyebutkan, dalam menyebarkan tentang ke-Syiah-annya, Dinasti Fatimiyah banyak menggunakan falsafat Yunani yang mereka kembangkan dari pemikiran-pemikiran Plato, Aristoteles dan ahli-ahli filsafat lainnya. Kelompok ahli filsafat yang paling terkenal pada masa Dinasti Fatimiyah ini adalah ikwan al-shofa. Dalam falsafatnya, kelompok ini

FatimiyahBani Fatimiyah.

5 Hasan Ibrahim Hasan, Tarikh Al-Daulah AlFathimiyah, Kairo, Jannatut Ta'lif, 1958, h. 436. 
lebih cenderung membela kelompok Syiah Ismailiyah, dan kelompok inilah yang mampu menyempurnakan pemikiran-pemikiran yang telah dikembangkan oleh golongan Mu'tazilah terutama dalam masalah-masalah yang berhubungan dengan ilmu, agama, pengembangan syariah dan filsafat Yunani. ${ }^{6}$

Dr. Hasan Asari dalam Menyingkap Zaman Keemasan Islam menjelaskan, pada masa klasik Islam, masjid mempunyai fungsi yang jauh lebih besar dan bervariasi dibading dengan fungsinya sekarang. Dulu, di samping sebagai tempat ibadah, masjid juga menjadi pusat kegiatan sosial dan politik umat Islam. Lebih dari itu masjid adalah lembaga pendidikan semenjak masa paling awal Islam. ${ }^{7}$ Hal yang sama juga terjadi di Masjid al-Azhar.

Pada masa Khalifah al-Mu'iz, Mesir berhasil ditaklukkan. Pahlawan penting dalam gerakan penyerbuan yang mengagumkan ini adalah Jauhar ash-Shiqilli, orang Sisilia. Aslinya adalah seorang Kristen yang lahir di daerah Bizantium, mungkin Sisilia, yang dari sana ia dibawa sebagai seorang budak ke Kairawan. Segera atas kemenangannya terhadap kota Fusthat pada tahun 969 M, Jauhar mulai mendirikan markas baru yang diberi nama alQahirah. Kota ini, Kairo modern, menjadi pusat kota Fatimiyah sejak tahun 973 M. Setelah mendirikan ibu kota baru, yang sekarang menjadi kota paling ramai di Afrika, Jauhar mendirikan Masjid Agung al-Azhar, yang kemudian oleh Khalifah al-Aziz dikembangkan menjadi universitas besar. ${ }^{8}$ Semenjak

6Ajid Thohir, Perkembangan Peradaban Di Kawasan Dunia Islam, Jakarta: Rajawali Pers, 2009, h. 116.

7 Hasan Asari, Menyikap Zaman Keemasan Islam,Bandung: Ciptapustaka Media, 2007.

8Ajid Thohir, Perkembangan Peradaban..., didirikannya, Masjid al-Azhar menjadi pusat pengkajian Islam dan pusat perkembangan ilmu pengetahuan bahkan sampai sekarang. ${ }^{9}$

Selain itu juga dikenal Dar al-Hikam atau dikenal juga Dar al-Ilmi yang didirikan oleh al-Hakim pada tahun $1005 \mathrm{M}$ sebagai pusat pembelajaran dan penyebaran ajaran Syiah ekstrim. Untuk mengembangkan institusi ini, al-Hakim menyuntikkan dana sebanyak 257 dinar di antaranya digunakan untuk menyalin berbagai naskah, memperbaiki buku dan pemeliharaan umum lainnya. Gedung ini dibangun berdekatan dengan istana kerajaan yang di dalamnya terdapat sebuah perpustakaan dan ruang-ruang pertemuan. Kurikulumnya meliputi kajian ilmu-ilmu ke-Islman, astronomi, dan kedokteran. Meskipun pada tahun 1119 ditutup oleh al-Malik al-Afdhal karena dianggap menyebarkan ajaran bid'ah, institusi ini masih bisa bertahan sampai kedatangan Bani Ayyubiyah. ${ }^{10}$

Pada masa dinasti ini, muncul sejumlah ulama dalam pelbagai disiplin ilmu pengetahuan. Bahkan, secara pribadi, al-Hakim sendiri tertarik pada perhitungan-perhitungan astrologi. Dia membangun di Muqattam sebuah observatorium yang sering ia kunjungi, sambil berjalan-jalan sebelum fajar menunggangi keledainya. Seorang nara sumber yang dikutip oleh sejarawan kontemporer, Ibnu Hammad, melihat sebuah perangkat terbuat dari tembaga menyerupai astrolobe yang didirikan oleh alHakim di atas dua menara untuk mengukur

h.117.

Ajid Thohir, Perkembangan Peradaban..., h. 114

9 Badri Yatim, Sejarah Peradaban Islam, Jakarta: Raja Grafindo Persada, 1998, cet.VII, h. 282.

10 Ajid Thohir, Perkembangan Peradaban..., h.117. 
tanda-tanda zodiak. Panjang astrolobe itu sekitar tiga jengkal.

Di antara pakar dan aktor intelektual pada dinasti ini adalah sebagai berikut:

\section{Ya'cub bin Killis}

Beliau adalah seorang wazir pada kekhalifahan al-Mu'iz dan al-Aziz. Ia adalah seorang Yahudi dari Baghdad yang masuk Islam. Berkat karir pilitiknya yang meningkat dan kecakapannya di bidang administrasi, berhasil meletakkan dasar-dasar ekonomi sehingga negeri itu mencapai kemakmuran di sepanjang sungai Nil. Dan dikabarkan Ibn Killis juga adalah tokoh dan pelopor perkembangan pendidikan pada kekhalifahan Fatimiyah di Mesir. Bahkan, Ya'cub rela rumahnya dijadikan tempat belajar bagi murud-muridnya. ${ }^{11}$

\section{Muhammad at-Tamimi}

Seorang dokter yang lahir di Yerusalam dan pindah ke Mesir sekitar tahun 970. Beliau adalah ahli fisika dan kedokteran. ${ }^{12}$

\section{Al-Kindi}

Muhammad bin Yusuf al-Kindi adalah seorang sejarawan ternama yang meninggal dunia di Fusthat pada tahun $961 \mathrm{M}$. Di antara karyanya adalah Kitab al-Wulah wa Kitab al-Qudhah. Buku ini telah diedit oleh R. Guest dan dicetak di Leiden pada tahun $1908 .{ }^{13}$

\section{Abu Hanifah An-Nu'man}

Beliau adalah ahli hukum dan pernah menjabat sebagai hakim.

\footnotetext{
h. 117. h.117.

12 Ajid Thohir, Perkembangan Peradaban...,

13 Ajid Thohir, Perkembangan Peradaban..., h.117.
}

11Ajid Thohir, Perkembangan Peradaban...,

\section{Ali ibn Yunus}

Seorang astronom hebat yang pernah dilahirkan Mesir ini meninggal pada tahun 1009, pada masa pemerintahan al-Hakim.

\section{Ali al-Hasan ibn al-Haitsami (w. $\pm 1039 \mathrm{M})$}

Ibnu Haitsam adalah peletak dasar ilmu fisika dan optik. Ia dilahirkan di Bashrah sekitar tahun 965. dalam bahasa Latin, ia lebih dikenal dengan sebutan Alhazen. Dalam pelbagai penelitiannya, ia pernah mencoba untuk mengatur aliran sungai Nil yang mengalir setiap tahun. Ketika percobaannya gagal, ia berpurapura gila dan menyembunyikan diri dari kemarahan sang khalifah, sampai sang khalifah meninggal dunia. Ia menulis tidak kurang dari seratus karya yang meliputi bidang matematika, astronomi, filsafat dan kedokteran. Karya terbesar yang patut dicatat adalah Kitab alMunazhir, mengenai ilmu optik. Edisi buku asli ini telah hilang, tetapi sudah diterjemahkan pada masa Gerald dari Cremona atau sebelumnya, dan sudah diterbitkan dalam bahasa Latin pada tahun 1572. kitab ini sangat berpengaruh terhadap perkembangan ilmu optik pada abad pertengahan. Hampir semua penulis tentang optik pada abad pertengahan menjadikan karya warisan Alhazen sebagai rujukan utama; karyakarya Roger Bacon, Leonardo da Vinci, dan Jonathan Kepler menunjukan adanya jejak-jejak pengaruh dari kitab itu. Dalam karyanya Ibnu alHaitsam menentang teori Euclid dan Ptolemius yang mengatakan bahwa mata mengirimkan cahaya visual pada objek yang dilihat. Ia juga melakukan percobaan untuk menguji sudut pantulan cahaya. Dalam beberapa percobaan tertentu ia mendekati penemuan teoritis tentang lensa pemesar yang menjadi prototipe lensa 
yang dibuat tiga abad kemudian di Italia.

\section{Ammar ibn Ali al-Maushili}

Karyanya adalah al-Muntakhab fi 'Ilaj al-Ayn, muncul di Mesir pada masa kekuasaan al-Hakim. Dalam hal ini para sejarawan menyatakan bahwa karya ini jauh lebih orisinal ketimbang Tadzkirah karya Ibnu Isa, ilmuan lain yang sezaman dengannya. Berkat kelengkapannya, kitab ini menjadi standar dalam disiplin penyakit mata, optalmologi. Ammar menjelaskan dasar-dasar operasi katarak yang belum parah dengan mengisapnya melalui lobang pembuluh. Praktek operasi ini merupakan salah satu penemuannya.

\section{Abu Abdillah An-Nasafi}

Ia telah menulis kitab al-Maushul. Kitab ini lebih banyak membahas masalah usul mazhab-mazhab Islam. Selahjutnya ia menulis kitab Unwanuddin, Ushulusyar'i, Adda'watu Munjiyah. Kemudian ia juga menulis buku tentang ilmu falak dan sifat alam dengan judul Kaunul alam dan al-Kaunul Mujraf. ${ }^{14}$

Pada masa al-Muntashir, kegagalan dan kemunduran kerajaan yang mengakibatkan berkurangnya harta kekayaan, pada gilirannya menyebabkan kemunduran lebih besar dengan banyaknya buku-buku yang hilang dari perpustakaan kerajaan. Perpustakaan itu sendiri mulai didirikan pada masa al-Aziz, dan ketika itu memiliki kurang lebih 200.000 buku dan 2.400 eksemplar al-Quran yang dihiasi ornamen-ornamen indah. Salah satu koleksi langkah perpustakaan ini adalah naskah-naskah hasil karya Ibnu Muqlah dan ahli-ahli kaligrafi

14 Hasan Ibrahim Hasan, Tarikh Al-Daulah AlFathimiyah,... h. 465-501. lainnya. Di perpustakaan ini pula al-Aziz menyimpan salinan tulis tangan buku sejarah karya at-Tabari. Dalam peristiwa perebutan rampasan perang pada tahun 1068, seorang sejarawan menyaksikan sekitar 25 ekor unta membawa pergi buku-buku itu. Naskah-naskah yang berharga itu digunakan sebagai bahan bakar untuk membakar rumah-rumah dan kantor-kantor orang Turki, sedangkan bagian sampulnya yang tebal dan mewah dijadikan untuk tambalan sepatu budak-budak mereka. ${ }^{15}$

\section{Lembaga-lembaga Pendidikan Pada Masa Daulah Fatimiyah di Mesir}

Perkembangan kebudayaan Islam pada masa ini mencapai kondisi yang sangat mengagumkan. Hal ini disebabkan berkembangnya penerjemahan dan penerbitan sumbersumber pengetahuan dari bahasa asing seperti bahasa yunani, Persia, dan India kedalam bahasa Arab yang banyak mendorong para wazir, sultan dan umara untuk melahirkan tokoh-tokoh ilmu pengetahuan dan sastra. Diantara lembaga-lembaga pendidikan pada Dinasti Fathimiyah antara lain:

\section{Masjid dan Istana}

Diceritakan salah seorang wazir dinasti ini Ya'qub bin Yusuf Ibn Killis sangat mencintai ilmu pengetahuan dan seni, sehingga setiap hari Kamis, ia selalu membacakan karangannya di depan masyarakat. Perkumpulan ini dihadiri oleh para hakim, fuqaha, ahli qiraat dan

15Mehdi nakosteen, Konstribusi Islam Atas Dunia Intelektual Barat Deskripsi Analisis Abad Keemasan Islam, Surabaya: Risalah Gusti, 1996, cet. I, h. 95. 
nahwa serta tokoh Hadits. Setelah ia selesai membacakan karangannya maka para ahli syair akan memujinya dengan pantun dan lagu.

Khalifah juga mengumpulkan para penulis di istana untuk menyalin buku-buku seperti: Al-Qur'an, Hadits, Fikih, Sastra serta ilmu Kedokteran, ia memberi penghargaan khusus bagi para ilmuwan ini dan menugaskan mereka untuk menjadi imam di masjid istana juga ${ }^{16}$. Begitu tingginya perhatian pemerintah terhadap ilmu pengetahuan hingga kebutuhan untuk penyalinan naskah tersebut pun tersedia seperti; tinta dan kertas.

Pada masa diasti ini mesjid juga menjadi tempat berkumpulnya ulama fiqih khususnya ulama yang menganut mazhab syiah ismailiyah juga para wazir dan hakim. Mereka berkumpul membuat buku tentang mazhab syiah ismailyah yang akan diajarkan kepada masyarakat. Diantara tokoh yang membuat buku itu antara lain: Yakop Ibn Killis, fungsi para hakim dalam perkumpulan ini adala untuk memutuskan perkara yang timbul dalam proses pembelajaran mazhab syiah tersebut ${ }^{17}$. Dengan demikian tanpak jelas lembaga-lembaga ini menjadi sarana penyebaran idiologi mereka. Hal senadadilakukan pada madrasah-madrasah Nidhamiah, seperti yang tertera dalam dokumen sifat-sifat

16 Hasan Ibrahim Hasan, Tarikh Al-Daulah AlFathimiyah,... h. 426.

17

Hasan Ibrahim Hasan, Tarikh Al-Daulah AlFathimiyah,... h. 427. madrasah dapat disimpulkan beberapa hal sebagai berikut yaitu:

a. Bahwa madrasah Nizhamiah, lengkap dengan harta wakaf dan penghasilan yang diperoleh dari pengelolaan harta tersebut, adalah untuk kepentingan satu kelompok tertentu, yang menganut mazhab Syafi'i.

b. Bahwa tiga dari lima jabatan (Mudarris, Wa'idh dan Pustakawan) harus dijabat oleh orang-orang bermazhab syiah.

Meskipun dokumen pendirian madrasah tidak mensyaratkan bahwa Nahwi dan Maq'ri harus bermazhab Syafi'i dalam praktek Nizham alMulk, tetapitetap mengangkat orangorang dari mazhab ini untuk kedua jabatantersebut. Tetapi ternyata lembaga pengembangan intelektual dalam hal ini madrasah pada masa klasik tidak hanya dijadikan sebagai sarana penyebaran suatu mazhab saja sebagaimana yang dilakukan pada dinasti Fathimiyah juga Abbasyiah pada masa Nizham al-Mulk.

Jadi dari beberapa paparan diatas member gambaran yang bahwa madrasah sebagai media pengembangan intelektualitas umat tidak hanya untuk pendidikan dan agama lebih dari itu terdapat juga motif politik dan social.

\section{Perpustakaan}

Perpustakaan juga memiliki peran yang sangat penting dalam penyebaran Akidah Syiah Ismailiyah di masyarakat. Oleh karena itu, para khalifah dan wazir memperbanyak pengadaan berbagai buku ilmu pengetahuan sehingga perpustakaan 
istana menjadi perpustakaan yang terbesar pada masa itu, yaitu pustaka "Dar al-Ulum" yang masih memiliki keterkaitan dengan perpustakaan "Baitul Hikmah" (perpustakaan dinasti Abbasiyah). Pustaka ini dibangun oleh Khalifah Fatimiyah al-Aziz yang berkuasa dari tahun 975-996 M, pada tahun 998. Berisikan tidak kurang dari 100.000 volume, boleh jadi 600.000 jilid buku termasuk 2.400 al-Qur'an yang berhiaskan emas dan perak yang disimpan diruang terpisah ${ }^{18}$.

Begitu besarnya pengaruh buku-buku yang diterjemahkan bagi penyebaran mazhab dinasti ini maka Ya'kub ibn Yusuf ibn Killis atas salah satu jasa khalifah Fatimiyahdi Kairo serta didorong oleh cendekiawan muslim, memperkerjakan banyak penyalin buku untuk menyalin buku-buku tentang undang-undang, kedokteran dan pengetahuan ilmiah. Ia menghabiskan 1000 dinar emas setiap bulan untuk dana bagi cendekiawan dan gaji para penyalin serta tukang jilid. ${ }^{19}$ Dukungan bagi perkembangan penerjemahan tidak hanya dilakukan oleh pemerintah tetapi tokoh-tokoh kaya dapat menyediakan tinta, kertas, mejameja serta ruangan bagi para ilmuan untuk belajar. Pada masa ini ilmuwan yang kekurangan biaya menerima pasongan untuk kehidupan selama studi. Dalam kondisi yang sangat kondusif ini

18 Mahdi Nakosteen, Kontribusi islam Atas..., h. 94 .

19 Mahdi Nakosteen, Konstribusi Islam atas..., h. $96-97$ maka bukan suatu kemustahilan bagi berkembangnya ilmu pengetahuan pada masa ini.

Begitu giatnya usaha penerjemahan buku ilmiah dan propaganda mazhab yang didukung oleh pemerintah tergambarkan sebagaimana yang diriwayatkan dari al-Maqrizy yang menyatakan bahwa diistana terdapa 40 lemari yang setiap lemari tersebut memiliki 18.000 volume buku. Dan perpustakaan ini sebagaimana dikatakan Abi Syamah sebagai salah satu keajaiban dunia di dalamnya juga dinyatakan terdapat sebanyak 1.220 naskah dari tarikh Thabari. ${ }^{20}$ Selain itu setelah alJuyusyi dan kekhalifahan digantikan oleh khalifah al-Amir, ia memindahkan sebanyak 500.000 jilid buku dari istana ke perpustakaannya sendiri. ${ }^{21}$

\section{Dar al-Ilm}

Pada bulan Jumadil Akhir tahun $395 \mathrm{H} / 1005 \mathrm{M}$ atas saran perdana mentrinya Ya'kub ibn Killis, khalifah al-Hakim mendirikan Jamiah ilmiah akademi (lembaga riset) seperti akademiakademi lain yang ada di Baghdad dan dibelahan dunia lain. Lembaga ini kemudia diberi nama Dar al-Hikmah. Disinilah berkumpul para ahli fiqih, astronomi, dokter dan ahli nahwu dan bahasa untuk mengadakan penelitian ilmiah. Al-Maqrizy mengatakan tentang hal ini sebagai berikut:

20 Hasan Ibrahim Hasan, Tarikh al-Islami..., h. 432.

21 Hasan Ibrahim Hasan, Tarikh al-Islami..., h. 432. 
Pada hari kedelapan saat Jumadil Tsani 309 H, bangunan yang di sebut Rumah Kebijaksanaan (Bait alHikmah) telah dibuka. Para mahasiswa mengambil tempat mereka. Bukubuku dipinjam dari perpustakaanperpustakaan di istana yang dijagatempat tinggal khalifah fatimiah- dan masyarakatpun diizinkan memasukinya. Siapapun bebas menulis yang diinginkan, atau siapa pun yang ingin membaca buku tertentu dapat dilakukan di perpustakaan itu. Di perpustakaan ini para pelajar dapat mempelajari Fikih Syiah, ilmu bahasa, ilmu falak, kedokteran, matematika, falsafah serta mantik. ${ }^{22}$

Gedung tersebut juga diperindah dengan karpet, dan pada semua pintu dan koridor terdapat tirai. Untuk perawatannya ditugaskan manajer, pelayan, penjaga dan pekerja kasar lainnya. Al-Hakim member hak masuk kepada setiap orang tanpa perbedaan tingkat, siapa yang ingin membaca dan menyalin buku ${ }^{23}$. Kemudia pada tahun $403 \mathrm{H}$ khalifah alHakim mulai mengadakan majlis ilmu rutin yang diadiri oleh ahli kesehatan, mantek,fiqih, kedokteran dan bersamasama mengkaji berbagai masalah ${ }^{24}$.

22Muhammad jamaluddin, Tarikh al-Hadharah al-Islamyah fi al-syarq, Dar al-Fikri al-Arabi, 1976, cet. IV, h. 238.

23 Mahdi Nakosteen, Konstribusi Islam Atas..., 1. 92 .

24 Hasan Ibrahim Hasan, Tarikh al-Islami..., h. 434.

\begin{abstract}
Begitulah al-Hakim sebagai khalifah terpelajar memfasilitasi segala yang berhubungan dengan perkembangan intelektual pada masa pemerintahannya. Walaupun dalam sejarah Dar al-Hikmah ini yang terkenal dengan pusat pendidikanpernah ditutup oleh sultan al-Malik al-Afdhal dikarenakan terdapat dua orang ilmuan tamu yang mengajarkan perkuliahan mengenai ajaran-ajaran yang menyeleweng (heretik) pada bagianbagian tertentu. ${ }^{25}$
\end{abstract}

\section{Kontribusi Dinasti Fatimiyah Dalam Kontek Kekinian Terhadap Dunia Islam Didunia}

Menunjukan Pertama, selama dua abad lebih Dinasti Fatimiyah menguasai Mesir, keberadaan Dinasti Fathimiyah telah memberikan sumbangan peradaban yang besar. Kemajuan terbesar adalah memberikan ruang berkembangnya ilmu pengetahuan di dunia Islam yang melahirkan banyak ilmuwan, tertatanya sistem administrasi pemerintahan yang membuahkan kemakmuran, terkenal dengan toleransi beragamanya. Kedua, Dinasti Fatimiyah adalah satu-satunya dinasti Syi'ah dalam Islam yang eksis selama kurang lebih dua setengah abad dan bisa berjaya melampaui capaian wilayah kekuasaan kerajaan-kerajaan Islam terdahulu, dan telah memberi banyak sumbangan peradaban terhadap dunia Islam, khususnya Mesir, karena pada masa Dinasti

25 Charles Michael Stanton, Pendidikan Tinggi Islam, Jakarta: Logos, 1998, h. 170. 
Fatimiyah ini, Mesir mengalami tingkat kemakmuran dan vitalitas kultural yang mengungguli Irak dan Baghdad sebagai pusat kekuasaan Islam kala itu. Dalam kontek pendidikan dinasti fatimiyah menjadi rujukan pada masa tersebut dibelahan dunia islam bahkan pada masa sekarang dan menjadi rujukan pendidikan dibelahan dunia islam.

\section{KESIMPULAN}

Motif pendirian Dinasti Fatimiyah adalah sebagai propaganda mazhab Syiah Ismailiyah yang dulunya selalu mendapat penindasan/ kecaman dari pemerintahan Abbasiyah. Dinasti ini bertahan dua setengah abad lamanya, dan terdiri dari empat belas khalifah yang kabarnya keturunan Fatimah az-Zahra puteri Rasul Saw. dan sekaligus isteri Ali bin Abi Thalib. sebagai sebuah perjalan kekuasaan yang cukup panjang, dinasti ini juga mengalami masa kemakmuran dan kemajuan serta masa kemunduran. Masa kemakmuran dan kemajuan dinasti ini adalah masa Khalifah al-Mu'iz dan puncaknya pada masa al-Aziz. Sedangkan masa kemundurannya pada pemerintahan al-Hakim sampai alAdid. Walaupun pada sisi tertentu intelektual pemerintahan al-Hakim memiliki kemajuan yang cukup pesat. Perkembangan intelektual pada dinasti ini memberi kontribusi yang besar bagi perkembangan ilmu pengetahuan dunia Timur dan Barat: meliputi perkembangan ilmu agama dan umum sehingga sampai sekarang pun masih dapat kita lihat perkembangannya.

\section{DAFTAR PUSTAKA}

Ali Ibrahim Hasan, Mashr fli 'Ushuril Wustha: Minal Fathil Arabiy ila Fathil
Utsmaniy, Kairo: Maktabah an-Nahdhah al-Mashriyah, 1976.

Ali Mufrodi, Islam dikawasan kebudayaan arab, Jakarta: Logos Wacana Ilmu, 1997.

Ajid Thohir, Perkembangan Peradaban di Kawasan Dunia Islam, Jakarta: Grafindo Persada, 2004.

Badri Yatim, Sejarah Peradaban Islam, Jakarta: Raja Grafindo Persada, cet. VII, 1998.

Charles Michael Stanton, Pendidikan Tinggi Islam, Jakarta: Logos, 1998.

Departemen Pendidikan Nasional, Ensiklopedi Islam,Jakarta: Ichtiar Baru Van Hoeve, 2001.

Hasan Asari, Menyingkap Zaman Keemasan Islam, Bandung: Ciptapustaka Media, 2007.

Hasan Ibrahim Hasan, Tarikh al-Islami,Kairo:

Maktabah al-Masriyah, 1967.

Hasan Ibraim Hasan,Tarikh ad-Daulah alFatimiyah fil Maghrib, Masr, Suriah wa Biladul Arab,Kairo: Lajnatut Ta'lif wal Tarjamah wan Nasyr, 1958.

http://id.wikipedia.org/wiki/Bani_ FatimiyahBani Fatimiyah.

http://fitrianimaduddin.wordpress. com/2010/01/07/dinasti-dinasti-lokaldan-akhir-sejarah-abasiyah/.

Mehdi Nakosteen, Konstribusi Islam Atas Dunia Intelektual Barat Deskripsi Analisis Abad Keemasan Islam, Surabaya: Risalah Gusti, 1996.

Muhammad Jamaluddin Surur, at-Daulah alFatimiyah fi Mashr,Kairo: Dar- al-Fikr al-Arabi, 1979.

Philip K. Hitti, History of The Arabs, penerjemah R. Cecep Lukman Yasin $d k k$.,Jakarta: Serambi, 2005.

Suwito, et al, Sejarah Sosial Pendidikan 
ISSN: 2085-2541

Islam, Jakarta: Kencana, 2005.

Syed Ameer Ali, The Spirit of Islam.
Diterjemahkan oleh Ahmadi Api Islam, Jakarta: Bulan Bintang, 1978. 